\title{
PENGARUH PELATIHAN TERHADAP KINERJA KARYAWAN PADA PT. SATRIA PIRANTI PERKASA DI KOTA TANGERANG
}

\author{
Lipia Kosdianti ${ }^{1}$, Didi Sunardi ${ }^{2}$ \\ Fakultas Ekonomi, Universitas Pamulang \\ Email: liviadianti96@gmail.com¹.dosen007240@unpam.ac.id²
}

\begin{abstract}
Purpose. This study aims to determine the effect of training on employee performance at PT. Satria Piranti Perkasa in Tangerang City.

Methods. Used is a quantitative descriptive method using the SPSS technique. The sample taken in this study is a saturated sampling technique, where the entire population is sampled, amounting to 110 people. The data collection technique used in this study was a questionnaire method. The data analysis used was validity test, reliability test, simple linear regression, correlation coefficient, determination coefficient, and hypothesis testing.
\end{abstract}

Findings. This study is a strong influence between training $(X)$ on employee performance $(Y)$ with regression $Y=7.352+0.815 X$, the regression coefficient is 0.815 , which means that training has a positive effect of 0.815 . The coefficient of determination is $41.5 \%$, while the remaining $58.5 \%$ is influenced by other factors. Hypothesis test obtained $t$-count $>t$-table or $(8,746>1,980)$, this is reinforced by a probability significance of $0.000<0.05$. Thus $\mathrm{HO}$ is rejected and Ha is accepted, meaning that there is a significant influence between Training on Employee Performance at PT. Satria Piranti Perkasa.

Implication. Companies should always pay attention to and provide opportunities for employees to take part in training, so that employee competencies can be maintained or improved and will support employee performance.

Keywords. Employee Training and Performance

\section{ABSTRAK}

Tujuan. Penelitian ini bertujuan untuk mengetahui pengaruh pelatihan terhadap kinerja karyawan pada PT. Satria Piranti Perkasa di Kota Tangerang.

Metode. Metode yang digunakan adalah metode deskriptif kuantitatif dengan menggunakan teknik SPSS. Sampel yang diambil dalam penelitian ini adalah teknik sampel jenuh, dimana seluruh populasi dijadikan sampel, yaitu berjumlah 110 orang. Teknik pengumpulan data yang digunakan dalam penelitian ini adalah metode angket/kuesioner. Analisis data yang digunakan yaitu uji validitas, uji reliabilitas, regresi linier sederhana, koefisien korelasi, koefisien determinasi, dan uji hipotesis.

Hasil. Penelitian ini adalah pengaruh yang kuat antara pelatihan $(X)$ terhadap kinerja karyawan $(Y)$ dengan regresi $Y=7,352+0,815 X$, angka koefisien regresi sebesar 0,815 yang berarti pelatihan berpengaruh positif sebesar 0,815 . Nilai koefisien determinasi sebesar 41,5\% sedangkan sisanya sebesar 58,5\% dipengaruhi oleh faktor lain. Uji hipotesis diperoleh t-hitung $>\mathrm{t}$-tabel atau $(8,746>1,980)$, hal ini diperkuat dengan probability significary $0,000<0,05$. Dengan demikian $\mathrm{H}_{0}$ ditolak dan $\mathrm{H}_{\mathrm{a}}$ diterima artinya terdapat pengaruh signifikan antara Pelatihan Terhadap Kinerja Karyawan Pada PT. Satria Piranti Perkasa. 
Implikasi. Perusahaan hendaknya selalu memperhatikan dan memberikan kesempatan kepada karyawan untuk mengikuti pelatihan, sehingga kompetensi karyawan dapat dipertahankan atau ditingkatkan dan akan menunjang kepada kinerja karyawan.

Kata Kunci. Pelatihan dan Kinerja Karyawan

\section{Pendahuluan}

Di dalam era globalisasi yang sangat erat dalam kemajuan teknologi dan perkembangan disegala bidang, membuat setiap perusahaan di Indonesia harus melakukan revolusi baru untuk dapat memenuhi tuntutan dari perkembangan zaman. Dengan adanya globalisasi, teknologi dan perubahan telah mempengaruhi lingkungan bisnis yang membutuhkan teknologi. Salah satu sumber daya organisasi yang memiliki peran penting dalam mencapai tujuannya adalah sumber daya manusia (SDM). Untuk itu sumber daya manusia dituntut menjadi unggul dan profesional dalam kerjanya demi kemajuan dan pencapaian tujuan perusahaan di Indonesia, agar dapat bersaing dalam era globalisasi.

Manajemen sumber daya manusia dapat didefinisikan sebagai suatu proses perencanaan, pengorganisasian, penyusunan staf, penggerakan dan pengawasan, terhadap pengadaan, pengembangan, pemberian kompensasi, pengintegrasian, dan pemeliharaan tenaga kerja untuk mencapai tujuan organisasi. Sumber dan pemeliharaan atas kemampuan menjadi arena bersaing dalam bentuk kompetisi. Dalam menghadapi persaingan yang ketat, perusahaan memerlukan sumber daya manusia yang profesional yaitu seseorang yang tidak hanya mampu melakukan dan menguasai tugas dengan landasan pengetahuan, melainkan juga mampu menaati peraturan yang ditetapkan perusahaan dalam rangka mencapai tujuan.

Upaya meningkatkan prestasi dari karyawan diperlukan karyawan yang terampil dan sesuai dengan keahlian yang dibutuhkan dibidangnya, sehingga perlu diadakan pelatihan bagi karyawan sebagai salah satu usaha meningkatkan kinerja karyawan. Pada tahun 1997 didirikan perusahaan baru yaitu PT. Satria Piranti Perkasa yang terletak di dalam Pelabuhan Jakarta. PT. Satria Piranti Perkasa merupakan perusahaan yang bergerak dibidang penyewaan, penjualan dan service heavy equipment (Forklift, Towing, Pallet, dll). PT. Satria Piranti Perkasa melayani pengiriman forklift keberbagai tempat di dalam dan di luar Pulau Jawa. PT. Satria Piranti Perkasa juga menawarkan paket sewa yang berbeda untuk pelanggan tergantung pada kebutuhannya. Beberapa pilihan yang ditawarkan dalam penyewaan adalah penyewaan secara borongan, harian (shift), kontrak jangka pendek dan juga kontrak jangka panjang. Pada akhir tahun 2011, PT. Satria Piranti Perkasa sudah mengoperasikan lebih dari 1839 unit Forklift Diesel, Forklift Listrik, Forklift liquefied petroleum gas (LPG) dan pada saat ini tahun 2019 PT. Satria Piranti Perkasa telah tumbuh dan berkembang dengan sangat cepat.

Adapun yang menyebabkan kurangnya kualitas kinerja yaitu disebabkan oleh penilaian kinerja yang tidak sesuai, sehingga karyawan tidak maksimal dalam mengerjakan tugasnya. Jika prestasi kerja lebih diperhatikan oleh perusahaan maka diharapkan keahlian yang dimiliki karyawan dalam pelatihan sumber daya manusia dapat meningkat sehingga kinerja karyawan dapat meningkat juga. Sutrisno (2017:68) mengatakan bahwa, pelatihan merupakan sarana ampuh mengatasi bisnis masa depan yang penuh dengan tantangan dan mengalami perubahan yang sedemikian cepat. Menurut peneliti Susanti (2018:47), hasil penelitian pengaruh Pelatihan dan komunikasi secara bersama memiliki pengaruh yang sangat berarti kepada kinerja. Pelatihan merupakan tanggung jawab seorang manajer untuk mengembangkan karyawan dalam sebuah perusahaan. Manajemen kini bersama-sama dengan para karyawan untuk mengidentifikasi tujuan dan sasaran strategis dalam mencapai tujuan perusahaan.

Para karyawan baru perlu diberikan pelatihan agar memiliki keterampilan yang sesuai kebutuhan dalam mengerjakan pekerjaannya. Untuk karyawan lama, pelatihan sumber daya manusia digunakan sebagai dasar peningkatan kemampuan dan perpindahan pekerjaan dan karyawan yang sudah lama bekerja akan dituntut tanggung jawab yang lebih besar, sehingga mengharuskan karyawan mengikuti pelatihan. Saat ini pelatihan diberikan kepada setiap karyawan dalam perusahaan termasuk karyawan administrasi maupun tenaga manajerial. 
PT. Satria Piranti Perkasa mengadakan pelatihan dengan melihat analisa permintaan, kepala divisi melaporkan akan kebutuhan pelatihan untuk bawahannya. Biasanya masalah akan peningkatan kualitas produk dan karyawan, dengan semakin pesatnya perkembangan teknologi para karyawan dituntut untuk meningkatkan kualitas dengan mengikuti pelatihan. Banyak fenomena yang terjadi dalam sebuah perusahaan rental forklif mengenai pelatihan kinerja karyawan. Masih rendahnya minat pelatihan di PT. Satria Piranti Perkasa, dengan karyawan yang sering menunda pekerjaan dan tidak datang pada saat pelatihan. Dengan adanya peraturan dan Standard Operation Procedure (SOP) yang ada dalam PT. Satria Piranti Perkasa setiap tahunnya Pelatihan wajib dilaksanakan dengan jumlah karyawan 30 pada tahun 2017, 40 pada tahun 2018, 50 pada tahun 2020 orang dalam setahun.

Berikut adalah tingkat pelatihan karyawan PT. Satria Piranti Perkasa pada tahun 2017 s.d. 2019 dapat dilihat pada tabel dibawah ini :

Tabel 1. Data Pelatihan Karyawan PT. Satria Piranti Perkasa Tahun 2017 s/d 2019

\begin{tabular}{|c|c|c|c|c|c|}
\hline Tahun & $\begin{array}{c}\text { Jumlah } \\
\text { Karyawan }\end{array}$ & $\begin{array}{c}\text { Target } \\
\text { Pelatihan }\end{array}$ & $\begin{array}{c}\text { Realisasi } \\
\text { Pelatihan }\end{array}$ & $\begin{array}{c}\text { Karyawan tidak } \\
\text { mengikuti pelatihan }\end{array}$ & Prosentase \\
\hline 2017 & 90 & 30 & 17 & 73 & $57 \%$ \\
\hline 2018 & 98 & 40 & 30 & 68 & $75 \%$ \\
\hline 2019 & 110 & 50 & 27 & 83 & $54 \%$ \\
\hline
\end{tabular}

Sumber : PT. Satria Piranti Perkasa (2020)

Berdasarkan Tabel 1 di atas dapat diketahui bahwa tingkat minat karyawan untuk mengikuti pelatihan karyawan dalam setiap tahun presentasenya kecil dan yang tidak mengikuti pelatihan cukup tinggi (jumlah peserta semakin menurun yang mengikuti pelatihan), dengan adanya program pelatihan ini dapat terlihat karyawan yang tidak mengikuti pelatihan lebih banyak dari pada yang mengikuti pelatihan. Ini menjadi perhatian penting dari perusahaan atas program kerja yang masih belum berjalan sesuai rencana dan tidak memenuhi Standard Operation Procedure (SOP). Meskipun upaya-upaya pelatihan telah dilaksanakan, karyawan masih cenderung tidak berminat dalam pelatihan tersebut.

Dalam perusahaan, pelatihan memiliki peran yang penting dalam meningkatkan kinerja karyawan. Pengukuran terhadap kinerja perlu dilakukan untuk mengetahui apakah dalam pelaksanaan kinerja terdapat rencana yang telah ditentukan atau apakah kinerja dapat dilakukan sesuai awal waktu yang ditentukan atau apakah hasil kinerja telah tercapai sesuai yang diharapkan. Untuk melakukan pengukuran tersebut, diperlukan kemampuan untuk mengukur kinerja karyawannya. Dengan tidak adanya sistem penilaian kinerja terhadap karyawan PT. Satria Piranti Perkasa membuat kinerja karyawan menjadi tidak sesuai dengan ketentuan perusahaan. Kinerja merupakan hasil kerja secara kualitas dan kuantitas yang dapat dicapai oleh seorang pegawai dalam melaksanakan tugas sesuai dengan tanggung jawab yang diberikan kepadanya.

Menurut Kasmir (2016:182) menyatakan bahwa, Kinerja adalah hasil kerja dan perilaku kerja yang telah dicapai dalam menyelesaikan tugas-tugas dan tanggung jawab yang diberikan dalam suatu periode tertentu. Penilaian prestasi kerja merupakan usaha yang dilakukan pimpinan untuk menilai hasil kerja bawahannya. Dengan adanya karyawan yang tidak mengikuti pelatihan tidak dapat meningkatkan kinerja yang direncanakan pihak manajemen. Manajemen tersebut harus merupakan suatu siklus atau tahapan, perencanaan, pelaksanaan, pemantauan dan evaluasi. Hasil evaluasi kinerja akan menjadi feedback bagi tahapan perencanaan berikutnya. Setiap perusahaan mengharapkan agar karyawannya dapat memiliki kinerja yang baik. Dengan pencapaian tersebut diperlukan sumber daya manusia yang memiliki kualitas, kuantitas, inisiatif, tanggung jawab dan dapat bekerjasama dengan sesama, pemahaman, dan dapat mengambil keputusan secara bersama dengan mengambil risiko yang kemungkinan yang akan terjadi. Dalam hal ini dapat dilihat target perbaikan unit tiap tahunnya yang memiliki SOP pada PT Satria Piranti Perkasa.

Berikut adalah data pencapaian target perbaikan unit pada kinerja karyawan di PT. Satria Piranti Perkasa, dapat dilihat pada tabel 2 berikut ini. 
Tabel 2. Data Kinerja Karyawan PT. Satria Piranti Perkasa Tahun 2017 s/d 2019)

\begin{tabular}{|c|c|c|c|}
\hline Tahun & $\begin{array}{c}\text { Target Perbaikan } \\
\text { Unit }\end{array}$ & $\begin{array}{c}\text { Realisasi Perbaikan } \\
\text { Unit }\end{array}$ & Persentase \\
\hline 2017 & 235 & 255 & $92,15 \%$ \\
\hline 2018 & 215 & 272 & $79,04 \%$ \\
\hline 2019 & 200 & 291 & $68,72 \%$ \\
\hline
\end{tabular}

Sumber : PT. Satria Piranti Perkasa (2020)

Berkaitan dengan Tabel 2 di atas, dapat dilihat dalam jumlah realisasi tiap tahunnya perbaikan unit meningkat melebihi target yang telah ditentukan hal ini menandakan bahwa kerusakan unit meningkat, hal ini disebabkan adanya penurunan dalam pengembangan sumber daya manusia yang dikarenakan masih banyak karyawan yang tidak mengikuti pelatihan. Perbaikan unit itu apabila perawatan yang dilakukan setiap bulannya terhadap mesin itu bagus, semestinya perbaikan unit setiap tahun menurun dari target yang ditentukan. Hal ini menjadi tugas manajemen pada suatu perusahaan untuk memberikan pelatihan para karyawan agar memiliki potensi, keahlian dan tanggung jawab dalam rangka upaya pencapaian tujuan perusahaan. Dalam hal ini perusahaan dituntut kemampuan atau kekuatannya untuk mengelola sumber daya secara terencana, terutama sumber daya manusia sebagai tenaga pelaksana operasional perusahaan untuk menghasilkan daya guna dan hasil guna dalam setiap kegiatan perusahaan.

Menurut Noratta dan Prabowo (2019:162) hasil penelitian pengaruh pelatihan dan motivasi terhadap kinerja karyawan adalah semua variabel bebas yang terdiri dari pelatihan dan motivasi terhadap kinerja karyawan adalah berpengaruh positif dan signifikan. Menurut peneliti Susanti (2018:47), hasil penelitian pengaruh Pelatihan dan komunikasi secara bersama memiliki pengaruh yang sangat berarti kepada kinerja. Dengan manfaat pelatihan kinerja karyawan menjadi lebih baik dan layak menjadi sumber daya manusia yang profesional dalam menjalankan tugas-tugasnya sebagai penguat fondasi karyawan agar tetap komitmen dalam pekerjaannya, dengan begitu karyawan patut dinilai kinerjanya, dan dalam realisasi pengembangan diri ini bermacam bentuk, antara lain melalui pendidikan yang lebih tinggi atau pelatihan peningkatan kemampuan.

Berdasarkan uraian yang telah dijelaskan, maka penulis merasa tertarik untuk melakukan penelitian dengan judul "Pengaruh Pelatihan Terhadap Kinerja Karyawan pada PT. Satria Piranti Perkasa di Kota Tangerang".

\section{Kajian Pustaka dan Hipotesis}

Pelatihan. Sutrisno (2017:66) mengatakan bahwa, pelatihan merupakan sarana ampuh mengatasi bisnis masa depan yang penuh dengan tantangan dan mengalami perubahan yang sedemikian cepat. Berdasarkan definisi di atas maka pelatihan dapat diartikan kegiatan yang dilakukan oleh suatu perusahaan untuk meningkatkan kemampuan karyawan berupa pengetahuan dan keahlian yang dapat dilakukan dalam bidang kerja masing-masing karyawan sesuai dengan kebutuhan dan kemampuan karyawan untuk menyelesaikan suatu pekerjaan.

Kinerja Karyawan. Mangkunegara (2017:67) menyatakan bahwa Pengertian kinerja (prestasi kerja) adalah hasil kerja secara kualitas dan kuantitas yang dicapai oleh seorang pegawai dalam melaksanakan tugasnya sesuai dengan tanggung jawab yang diberikan kepadanya.

\section{Hipotesis}

H0. Tidak terdapat pengaruh yang signifikan antara pelatihan kerja dengan kinerja karyawan pada PT. Satria Piranti Perkasa.

Ha. Terdapat pengaruh yang signifikan antara pelatihan kerja dengan kinerja karyawan pada PT. Satria Piranti Perkasa. 


\section{Metode Penelitian}

Sugiyono (2017: 244) mengemukakan analisis data adalah proses mencari dan menyusun secara sistematis data yang diperoleh dari hasil wawancara, catatan lapangan, dan dokumentasi, dengan cara mengorganisasikan data ke dalam kategori, menjabarkan ke dalam unit-unit, melakukan sintesa, menyusun ke dalam pola, memilih mana yang penting dan yang akan dipelajari, dan membuat kesimpulan sehingga mudah dipahami oleh diri sendiri maupun orang lain.

Untuk menganalisa pengaruh pelatihan pada PT. Satria Piranti Perkasa, penulis terlebih dahulu melakukan.

\section{Uji Instrumen Penelitian}

Adapun dalam pengujian instrumen ini digunakan 2 (dua) pengujian yaitu validitas dan reliabilitas.

\section{Uji Koefisien Korelasi}

Untuk menentukan tingkat korelasi hubungan $\mathrm{x}$ dan $\mathrm{y}$ dapat ditentukan dengan tabel interpal nilai koefesien dan kekuatan hubungan berikut ini:

Tabel 3. Pedoman Interprestasi Koefesien Korelasi

\begin{tabular}{|c|c|}
\hline Interval Nilai Koefesien Korelasi & Tingkat Hubungan \\
\hline $0,000-0,199$ & Sangat Rendah \\
\hline $0,200-0,399$ & Rendah \\
\hline $0,400-0,599$ & Sedang \\
\hline $0,600-0,799$ & Kuat \\
\hline $0,800-1,000$ & Sangat Kuat \\
\hline
\end{tabular}

Sumber : Sugiyono $(2017: 184)$

Semakin tinggi koefesien korelasi $\left(\mathrm{r}_{\mathrm{xy}}\right)$ antara dua variabel bebas $(\mathrm{X})$ dan variabel terikat (Y), maka tingkat keeretan pengaruh antara dua variabel tersebut semakin tinggi sebaliknya.

\section{Analisis Koefisien Determinasi}

Menurut Sujarweni (2018:190), koefisien determinasi $\left(\mathrm{r}^{2}\right)$ digunakan untuk mengukur seberapa jauh kemampuan variabel - variabel dependen. Nilai koefesien determinasi $\left(\mathrm{r}^{2}\right)$ adalah antara nol dan satu. Nilai $\mathrm{r}^{2}$ yang kecil berarti kemampuan variabel-variabel independen dalam menjelaskan variabel dependen amat terbatas. Adapun ketentuan besarnya nilai koefisien determinasi (KD) antara 0 (nol) sampai dengan 1 (satu), dimana rumus koefisien determinasi dan interpretasinya sebagai berikut :

$\mathrm{KD}=\mathrm{r}^{2} \mathrm{x} \mathbf{1 0 0 \%}$

Keterangan :

$\mathrm{KD}=$ Koefisien Determinasi

$\mathrm{r}^{2} \quad$ = Nilai korelasi antara X terhadap $\mathrm{Y}$

\section{Analisis Regresi Linear Sederhana}

Menurut Amelia (2018:45) analisis regresi sederhana digunakan untuk mengetahui ada tidaknya pengaruh dari variabel bebas terhadap variabel terkait. Sehingga yang akan kita ketahui adalah variabel bebas $\mathrm{X}$ terhadap terikat $\mathrm{Y}$. Adapun persamaan regresinya dapat dilihat pada persamaan di bawah ini:

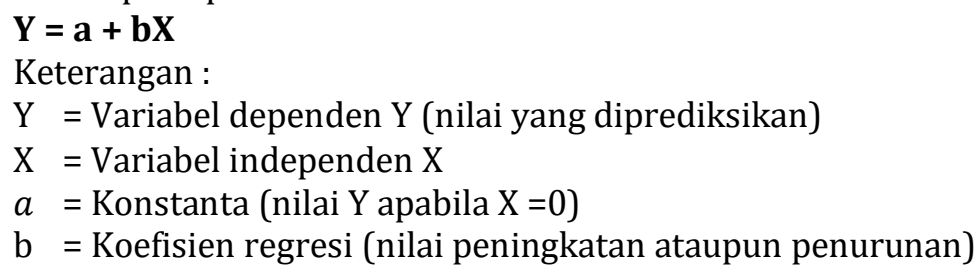




\section{Uji Hipotesis}

Menurut Sugiyono (2017:284) hipotsesis merupakan jawaban sementara terhadap rumusan masalah penelitian yang diajukan, maka titik tolak ukur untuk merumuskan hipotesis adalah rumusan masalah dan kerangka berfikir. Uji t dilakukan untuk mengetahui apakah variabel indefenden secara varisial mempengaruhi variabel defenden dengan asumsi variabel indefenden lainnya konstan. Untuk mengetahui signifikansi analisis jalur, kita bandingkan nilai probabilitas signifikansi. Apabila p value $>0,05$, maka Ho ditolak dan Ha diterima (model regresi signifikan), dan sebaliknya. Dalam penelitian ini rumusan hipotesis yang dibuat adalah sebagai berikut:

$t=\frac{r \sqrt{n-2}}{\sqrt{1-r^{2}}}$

Keterangan :

$\mathrm{T}$ = t-hitung yang selanjutnya dibandingkan dengan $\mathrm{t}$-tabel

$r=$ Koefisien korelasi

$\mathrm{n}=$ Jumlah sampel

$\mathrm{r}^{2}=$ Kofiesien determinasi

\section{Hasil Penelitian dan Pembahasan}

\section{Uji Validitas Instrumen}

Tabel 4. Hasil Uji Validitas

\begin{tabular}{|c|c|c|c|}
\hline Pernyataan & $\mathbf{r}_{\text {hitung }}$ & $\mathbf{r}_{\text {tabel }}$ & Keterangan \\
\hline \multicolumn{4}{|l|}{ Pelatihan (X) } \\
\hline 1 & 0,689 & 0.195 & Valid \\
\hline 2 & 0,510 & 0.195 & Valid \\
\hline 3 & 0,503 & 0.195 & Valid \\
\hline 4 & 0,502 & 0.195 & Valid \\
\hline 5 & 0,523 & 0.195 & Valid \\
\hline 6 & 0,504 & 0.195 & Valid \\
\hline 7 & 0,551 & 0.195 & Valid \\
\hline 8 & 0,502 & 0.195 & Valid \\
\hline 9 & 0,559 & 0.195 & Valid \\
\hline 10 & 0,508 & 0.195 & Valid \\
\hline \multicolumn{4}{|c|}{ Kinerja Karyawan (Y) } \\
\hline 1 & 0,747 & 0.195 & Valid \\
\hline 2 & 0,472 & 0.195 & Valid \\
\hline 3 & 0,503 & 0.195 & Valid \\
\hline 4 & 0,468 & 0.195 & Valid \\
\hline 5 & 0,744 & 0.195 & Valid \\
\hline 6 & 0,575 & 0.195 & Valid \\
\hline 7 & 0,782 & 0.195 & Valid \\
\hline 8 & 0,754 & 0.195 & Valid \\
\hline 9 & 0,557 & 0.195 & Valid \\
\hline 10 & 0,520 & 0.195 & Valid \\
\hline
\end{tabular}

Sumber pengolahan Data SPSS 24, (2020)

Berdasarkan data tabel di atas, variabel Pelatihan dan Kinerja Karyawan diperoleh nilai $r$ hitung $>r$ tabel (0.195), dengan demikian maka semua item kuesioner dinyatakan valid. Untuk itu kuesioner yang digunakan layak untuk diolah sebagai data penelitian. 
Tabel 5. Hasil Uji Reliabilitas

\begin{tabular}{|l|c|c|c|}
\hline \multicolumn{1}{|c|}{ Variabel } & Cronbatch Alpha & $\begin{array}{c}\text { Standar Cronbatch } \\
\text { Alpha }\end{array}$ & Keputusan \\
\hline Pelatihan (X) & 0.710 & 0.600 & Reliabel \\
\hline Kinerja Karyawan (Y) & 0.818 & 0.600 & Reliabel \\
\hline
\end{tabular}

Sumber pengolahan Data SPSS 24, (2020)

Dari hasil uji reliabilitas di atas didapatkan semua nilai dari hasil variabel Pelatihan menghasilkan nilai alpha cronbach $(0,710)>0,60$ dan variabel Kinerja menghasilkan nilai alpha cronbach $(0,818)>0,60$. Sehingga dapat disimpulkan bahwa instrumen dalam penelitian ini reliabel

\section{Uji Koefisien Korelasi}

Tabel 6. Hasil Uji Koefisien Korelasi

\begin{tabular}{|c|c|c|c|}
\hline \multicolumn{4}{|c|}{ Correlations $^{\mathbf{b}}$} \\
\hline & & Pelatihan & Kinerja \\
\hline \multirow[t]{2}{*}{ Pelatihan } & Pearson Correlation & 1 & $644^{* *}$ \\
\hline & Sig. (2-tailed) & & 000 \\
\hline \multirow[t]{2}{*}{ Kinerja } & Pearson Correlation & ,644** & 1 \\
\hline & Sig. (2-tailed) & 000 & \\
\hline \multicolumn{4}{|c|}{ **. Correlation is significant at the 0.01 level (2-tailed). } \\
\hline \multicolumn{4}{|c|}{ b. Listwise $\mathrm{N}=110$} \\
\hline
\end{tabular}

Berdasarkan tabel di atas, dapat dikemukakan bahwa nilai korelasi variabel pelatihan kerja dengan sebesar 0,644 masuk kategori "Kuat". Dengan kata lain, terdapat hubungan yang Kuat antara variabel pelatihan dengan kinerja.

\section{Regresi Linier Sederhana}

Penilaian analisis regresi bertujuan untuk mengetahui seberapa besar pengaruh pelatihan terhadap kinerja karyawan. Dalam uji regresi linear sederhana maka terlebih dahulu ditentukan nilai t-tabel sebagai pembanding dengan cara:

Df $\quad=\mathrm{n}-\mathrm{k}$

Nilai sig $=0,05$

Keterangan :

Df (degree of freedom)

$\mathrm{n} \quad=$ jumlah sampel (sampel dalam penelitian ini sebanyak 110)

$\mathrm{k}=$ jumlah variabel bebas dan terikat (2)

Df $=110-2=108$

Sehingga dengan nilai t-tabel dalam sugiyono (2017:332), maka diperoleh nilai t-tabel sebesar 1,980. Berikut di bawah ini hasil uji t dalam penelitian ini

Tabel 7. Hasil Uji Regresi Linear Sederhana

\begin{tabular}{|c|c|c|c|c|c|c|}
\hline \multicolumn{7}{|c|}{ Coefficients $^{a}$} \\
\hline & & \multicolumn{2}{|c|}{ Unstandardized Coefficients } & $\begin{array}{l}\text { Standardized } \\
\text { Coefficients }\end{array}$ & \multirow[b]{2}{*}{$\mathrm{t}$} & \multirow[b]{2}{*}{ Sig. } \\
\hline \multicolumn{2}{|c|}{ Model } & B & Std. Error & Beta & & \\
\hline \multirow[t]{2}{*}{1} & (Constant) & 7,352 & 2,224 & & 3,306 & ,001 \\
\hline & Pelatihan & 815 & 093 & 644 & 8,746 &, 000 \\
\hline
\end{tabular}

Sumber pengolahan Data SPSS 24, (2020) 
Berdasarkan tabel tersebut dapat dikemukakan sebagai berikut :

Persamaan regresi $\mathrm{Y}=\mathbf{7 , 3 5 2}+\mathbf{0 , 8 1 5 X}$

t-hitung $\quad=8,746$

Keterangan tersebut, dapat dijelaskan sebagai berikut:

a. Nilai konstanta sebesar 7,352 dapat disimpulkan bahwa nilai konstanta sebesar 7,352, apabila variabel X tidak ada atau konstan maka telah terdapat Pelatihan sebesar 7,352.

b. Variabel pelatihan terbukti berpengaruh positif signifikan terhadap kinerja, dalam hal ini dapat ditunjukkan oleh nilai koefesien regresi sebesar 0,815, nilai t-hitung sebesar 8,746 lebih besar dari 1,980 $(8,746>1,980)$ lebih kecil dari 0,005 $(0,000<0,05)$.

\section{Uji Determinasi}

Tabel 8. Hasil Uji Determinasi

\begin{tabular}{|l|c|r|c|r|}
\hline \multicolumn{5}{|c|}{ Model Summary } \\
\hline Model & $\mathrm{R}$ & R Square & $\begin{array}{c}\text { Adjusted R } \\
\text { Square }\end{array}$ & $\begin{array}{c}\text { Std. Error of } \\
\text { the Estimate }\end{array}$ \\
\hline 1 &, $644^{\mathrm{a}}$ &, 415 &, 409 & 5,772 \\
\hline \multicolumn{7}{|c|}{ a. Predictors: (Constant), Pelatihan } \\
\hline
\end{tabular}

Sumber pengolahan Data SPSS 24, (2020)

Dari tabel di atas bahwa nilai adjust $R$ Square adalah sebesar 0,415 hal ini berarti 41,5\%, maka dapat disimpulkan bahwa variabel pelatihan (X) memiliki konstribusi pengaruh terhadap variabel kinerja karyawan sebesar $41,5 \%$ sedangkan sisanya $(100 \%-41,5 \%=$ $58,5 \%$ ) dijelaskan oleh variabel lain yang tidak dibahas dalam penelitian ini.

\section{Uji Hipotesis}

Tabel 9. Hasil Uji t Pelatihan Terhadap Kinerja Karyawan

\begin{tabular}{|c|c|c|c|c|c|c|}
\hline \multicolumn{7}{|c|}{ Coefficients ${ }^{\mathbf{a}}$} \\
\hline \multirow{2}{*}{\multicolumn{2}{|c|}{ Model }} & \multicolumn{2}{|c|}{ Unstandardized Coefficients } & \multirow{2}{*}{\begin{tabular}{|c|}
$\begin{array}{c}\text { Standardized } \\
\text { Coefficients }\end{array}$ \\
Beta
\end{tabular}} & \multirow[b]{2}{*}{$\mathrm{t}$} & \multirow[b]{2}{*}{ Sig. } \\
\hline & & $\mathrm{B}$ & Std. Error & & & \\
\hline \multirow[t]{2}{*}{1} & (Constant) & 7,352 & 2,224 & & 3,306 & 001 \\
\hline & Pelatihan & 815 & ,093 & ,644 & 8,746 &, 000 \\
\hline
\end{tabular}

Sumber pengolahan Data SPSS 24, (2020)

Dari tabel di atas diperoleh nilai t-hitung $>\mathrm{t}$-tabel $(8,746>1,980)$ dari nilai signifikan $0,000<0,05$ maka dapat disimpulkan bahwa variabel Pelatihan $(\mathrm{X})$ secara parsial berpengaruh positif dan signifikan terhadap kinerja karyawan (Y) atau dengan kata lain Ho ditolak dan Ha diterima, hal ini dapat diketahui dan akan menunjukkan bahwa terdapat pengaruh yang positif dan signifikan antara variabel pelatihan terhadap kinerja karyawan pada PT. Satria Piranti Perkasa.

\section{Kesimpulan}

Adanya pelatihan yang diberikan kepada karyawan PT. Satria Piranti Perkasa kurang baik hal ini dapat dilihat dari hasil pernyataan kuisioner penulis menyimpulkan tentang butir pelatihan mendapatkan kategori penilaian, pada hasil jawaban seluruh responden yang berjumlah 110 pengguna dengan pernyataan, yang menjawab "Sangat Setuju" yaitu sebesar $(3,91 \%)$ dan "Setuju" sebesar (17\%). Kinerja kerja karyawan PT. Satria Piranti Perkasa kurang baik hal ini terlihat dari hasil jawaban responden yang diisi ke dalam kuisioner pernyataan yaitu untuk kategori penilaian pada hasil jawaban seluruh responden yang berjumlah 110 pengguna dengan pernyataan, yang menjawab "Sangat Setuju" yaitu sebesar $(8,82 \%)$ dan 
"Setuju" sebesar (22,9\%). Kinerja karyawan PT. Satria Piranti Perkasa sudah terbukti baik untuk para klien yang bekerja sama. Berdasarkan analisis yang telah penulis lakukan, analisis regresi berfungsi untuk mengetahui pengaruh variabel independen terhadap variabel dependen, dalam hal ini Pelatihan $(\mathrm{X})$ berpengaruh signifikan terhadap kinerja karyawan $(\mathrm{Y})$ dengan persamaan regresi $Y=7,352+0,815$. Nilai koefesien korelasi sebesar 0,644 artinya kedua variabel memiliki tingkat pengaruh yang "kuat" dengan koefesien determinasi sebesar $41,5 \%$. Uji hipotesis diperoleh t-hitung > t-tabel atau $(8,746>1,980)$, hal ini diperkuat dengan probability signifikansi antara Pelatihan terhadap Kinerja Karyawan pada PT. Satria Piranti Perkasa

\section{Daftar Pustaka}

Abdullah, M. (2014). Manajemen dan Evaluasi Kinerja Karyawan. Yogyakarta: Penerbit Aswaja Pressindo.

Anwar Prabu Mangkunegara, (2014), Evaluasi Kinerja SDM, Cetakan Ketujuh, Refika Aditama, Bandung.Cetakan Ke-22 Bandung: Alfabeta.

Anwar Prabu Mangkunegara, (2015). Sumber Daya Manusia Perusahaan. Cetak Kedua Belas. Bandung: PT. Remaja Rosdakarya.

Asra, Abuzar dan Achmad Prasetyo (2015). Pengambilan Sampel dalam Data perusahaan, Pt. Mitra Permata Indah, yang diakses pada tanggal 12 Desember 2019.

Edison, Emron. Yohny anwar, Imas komariyah. (2016). Manajemen Sumber Daya Manusia. Bandung: Alfabeta.

Edy, Sutrisno, (2016), Manajemen Sumber Daya Manusia, Kencana Prenada Media Group, Jakarta.

Ghozali, (2014). Aplikasi analisis Multivariate dengan Program SPSS. Badan Penerbit UNDIP , Semarang.

Hasibuan, Malayu S.P. (2017). Manajemen Sumber Daya Manusia. Edisi.Revisi. Jakarta: Penerbit PT Bumi Aksara.

Hasibuan, Malayu S.P. (2014). Manajemen Sumber Daya Manusia. Edisi Revisi. Jakarta: BumiAksara.

Husein, Umar. (2014). Metode Penelitian untuk Skripsi dan Tesis Bisnis. Jakarta : PT.Raja Grafindo Persada.

Istijanto. (2010). Riset Sumber Daya Manusia Edisi Revisi. Yogyakarta: PT. Gramedia Pustaka Utama.

Kartono dan Kartini. (2014). Pemimpin dan Kepemimpinan. Jakarta : PT Raja Grafindo Persada.

Kartono, Kartini. (2016). Pemimpin Dan Kepemimpinan. Jakarta: Rajawali Pers.

Malayu S.P. Hasibuan. (2016). Manajemen : Dasar, Pengertian, Dan Masalah, Edisi Revisi, Bumi Aksara, Jakarta.

Mulyadi. (2015). Manajemen Sumber Daya Manusia. Jakarta; Penerbit In Media. Perusahaan . Edisike-7. Depok: PT RAJAGRAFINDO.Revisi. Jakarta: Penerbit PT Bumi Aksara.

Nazir, Moh. (2014). Metode Penelitian. Bogor: Ghalia Indonesia

Arikunto, Suharsimi. (2014). Prosedur Penelitian Suatu Pendekatan Praktik. Jakarta Rineka Cipta

Rivai, Veithzal "Manajemen Sumber Daya Manusia Dari Teori Kepraktik" Jakarta: PT. Raja Grafindo Persada. 2014. 
Robbins, Stephen P. and Mary Coulter. (2016). Manajemen, Jilid 1 Edisi 13, Alih Bahasa: Bob Sabran Dan Devri Bardani P, Erlangga, Jakarta.

Sadili Samsudin. (2014). Manajemen Sumber Daya Manusia. Bandung: Pustaka Setia.

Sugiyono, (2015), Metode Penelitian Kuantitatif, Kualitatif, dan R\&D, .

Sugiyono. (2014) Metode Penelitian Kuantitatif Kualitatif dan R\&D. Bandung:Alfabeta.

Sutrisno, (2014), Manajemen Sumber Daya Manusia, Jakarta : Prenada Media Group.

Suyadi, Prawirosentono. (2014). Manajemen Sumber Daya Manusia Kebijakan Kinerja Karyawan. Yogyakarta: BPFE.

Tampubolon, Biatna Dulbert. (2017) "Analisis Faktor Gaya Kepemimpinan Dan Faktor Etos Kerja Terhadap Kinerja Pegawai Pada Organisasi Yang Telah Menerapkan SNI 19-90012001," Jurnal Standarisasi, 9 (January 2007), hal. 106-115.

Wibowo. (2017). Manajemen Kinerja. Edisi Kelima. Depok: PT. Raja Grafindo Persada. 